\title{
Company accused over lab data 'theft'
}

[SAN DIEGO] A small biotechnology company is being sued for allegedly making use of data that it is said to have stolen from a chemistry laboratory at the University of California at San Diego (UCSD).

Agouron Pharmaceuticals, Inc. of La Jolla is accused of taking data on the crystallization of an enzyme which its scientists used in a published article, and then in research aimed at developing an anticancer drug.

The lawsuit has been filed by Huguette Pelletier, now an assistant professor of biochemistry at Baylor College of Medicine in Houston, Texas. It could cause difficulties for Agouron, a publicly traded company whose shares have been riding high recently after it obtained federal approval for a new protease inhibitor as a potential anti-HIV drug.

The lawsuit centres on the activities of two Agouron researchers, Jay F. Davies II and his wife, Michele A. McTigue. Davies is the first author of the 1994 article, which describes the characteristics of the enzyme rat DNA polymerase $\beta$. He has also published articles on Agouron's protease-inhibitor project.

Both Davies and McTigue are former doctoral graduates of the UCSD chemistry programme, McTigue graduating in 1992. McTigue is being accused by Pelletier of using her personal access to facilities in the UCSD laboratory of Joseph Kraut to secure the polymerase $\beta$ data secretly for her husband, possibly by copying data stored on computer.

Pelletier also obtained her chemistry doctorate in Kraut's laboratory. Kraut, who is professor emeritus of chemistry and biochemistry, and is supporting Pelletier's allegation of McTigue's theft of enzyme data, was a co-founder of Agouron. But he cut his links with the company before the dispute arose because of a disagreement about strategy.

Davies and McTigue have denied Pelletier's claims, and Gary E. Friedman, an attorney with Agouron, denies that the company has acted improperly, saying that the allegations "aren't supported by the facts". (Agouron officials declined to be interviewed on the allegations.)

The allegation was first made in 1994, when Pelletier filed the lawsuit in San Diego Superior Court. After a three-year legal battle over her right to claim ownership of the data - which Agouron's attorney had disputed - Pelletier won a key legal decision from California's 4th District Court of Appeal last month, enabling her to sue the company.

The case will now go to trial in the Superior Court, where it is being assigned a new judge because the judge who had originally ruled erroneously in favour of Agouron has since resigned following a drunken-driving conviction.

The Agouron article in question - the first on crystallization of rat DNA polymerase $\beta$ - was published in the journal Cell in March 1994 (76, 1123-1133; 1994). Pelletier and Kraut have since written a number of letters to the editor of Cell, Benjamin Lewin, seeking assistance in resolving what they call several "scientific discrepancies" and "misleading" statements in the Agouron paper.

Pelletier has also urged Cell to persuade the Agouron team to file all the back-up data for the crystallography - coordinates and structure factors - with the Protein Data Bank at Brookhaven National Laboratory in New York state.

After the first letter to Cell in September 1994 , one set of coordinates was filed with the data bank. But records show that no corresponding structure factors were filed, and coordinates on other crystallography in the paper have yet to be lodged at the data bank.

Pelletier claims that the Agouron research team has been dragging its feet on filing the data because publication might reveal data that were generated by her.

Pelletier's research on polymerase $\beta$ was eventually published in October 1996 in Biochemistry $(35,12742-12761 ; 1996)$. She blames the delay on Agouron, in particular its publication of the paper containing what she claims to be her data. Discrepancies between her paper and that published by Agouron have already prompted considerable debate among crystallographers.

Rex Dalton

\section{Tighter evaluation urged for Japan's public research bodies}

[токуо] A report aiming to formulate guiding principles by which all publicly funded research in Japan - including that carried out in industry - should be evaluated was released last week by an advisory body attached to the prime minister's office.

The report, by a subcommittee of the Council for Science and Technology, concedes that the present state of research evaluation in Japan is "very unsatisfactory". It says that evaluation is central to the building up of a new research system, and that the results of evaluation exercises should be fed directly into future funding decisions.

But it does not make any suggestions about how this should be achieved. And the choice of evaluation practices and the procedures by which they are to be implemented is left to individual research institutions and the funding bodies that oversee them.

Guidelines for assessing research in national institutes were first issued by the council in 1986. But a recent review showed that fewer than one third of Japan's public research centres had put the recommendations into practice.

Many observers feel that the report's recommendations are largely token measures intended to ensure that funding for science is maintained at a time when there are growing political pressures to reform the country's national budget. They also criticize its lack of consideration of how to assess research policies.

"What we need in Japan is a broad discussion on the practicalities of research funding", says Shinichi Kobayashi, a science policy analyst at the University of ElectroCommunications in Chofu, near Tokyo. "Policy and programme evaluation should come first."

Kobayashi says that many research funding bodies do not have the means to carry out their work properly, citing the Ministry of Education's general university grants scheme as an example. Funds allocated through the scheme have more than trebled in recent years. But roughly 100,000 applications a year continue to be processed by only seven administrative staff.

Masahiro Kawasaki, vice-president of the Japan Science and Technology Corporation, a funding body attached to the Science and
Technology Agency, says that the report concerns mainly the "basic methodological aspects" of evaluation. "Policy considerations will have to follow”, he says.

Much depends on how individual agencies, research institutions and universities implement the new guidelines. The Ministry of International Trade and Industry's Agency for Industrial Science and Technology (AIST) has already announced plans to set up a division for research evaluation in July. But similar initiatives at other ministries are said to have been blocked by the finance ministry.

According to an official at AIST, all future proposals for research projects will have to undergo an initial peer review. Accepted projects will be reviewed at least once during their lifetimes, and all projects will be limited to five years. Until recently, research consortia financed by AIST were evaluated only after they had finished their work, and against goals defined at the outset. But, as the final evaluation was usually done by those responsible for the project, the results "were often manipulated to correspond to initial project goals", says an official at the agency.

Robert Thiend 